\title{
Protection Analysis Of Children Rights That Was Born From The Rape Causing (Study in State Court (PN) in Ex-Residency Cirebon Jurisdiction)
}

\begin{abstract}
Endang Kusnandar ${ }^{1}$, Anis Mashdurohatun ${ }^{2}$, Siti Rodhiyah Dwi Istinah ${ }^{3}$
Abstract. Criminal cases of rape very much creates difficulties in solving both at the stage of investigation, prosecution, or at the stage of the imposition of the verdict. The problems of this study are: forms of legal protection given to the rights of Children Which Born fom rape victims in Ex Residency Cirebon Jurisdiction and constraints in the implementation of the provision of legal protection against rape victims in Ex Residency Cirebon Jurisdiction and solutions. The method used by researchers is normative juridical law approach and specification in this study were included descriptive analysis. The source and type of data in this study are primary data obtained from field studies with interview members of the Police of Ciwaringin Cirebon, And secondary data obtained from the study of literature.

Based on the results of research that as is the case in jurisdictions other areas, merely enacted regional regulation on Child Protection, but the regulation is not set up for a child born to mothers who were raped or pregnancy due to rape, as well as court decisions, no one has noticed the rape victims who become pregnant as a result of rape, either already known or unknown since the trial process after the imposition of the verdict (ponis), as well as the Agency duties and authorities are not up to provide protection to Children Which Born from rape, but the child of such status as well as victims. Obstacles such as the difficulty to obtain information from the victim because of the victim's mental condition of the child, still quite a lot of people who are reluctant to testify as a witness, investigators have no children, as well as the infrastructure is not yet complete. To overcome the obstacles faced by those already undertaken several measures, among others cooperate with relevant agencies to provide protection and assistance to child victims of rape, bring in psychologists to recover the child's mental disturbed for being a victim of rape cases, as well as trying to convince the witness that willing to give information and not to be afraid to provide testimony.

Keywords : Rights Protection; Children; Rape.
\end{abstract}

\section{Introduction}

Constitution of the Republic of Indonesia 1945, in Article 28D (1) states that: "Everyone has the right to recognition, security, protection, and legal certainty as well as equal treatment before the law". However, the implementation and the regulations issued by the lawmakers in this regard the Government and Parliament of the Republic of Indonesia (DPR RI) is not in line with the wording of Article 28D (1) is.

Criminal cases of rape very much creates difficulties in solving both at the stage of investigation, prosecution, or at the stage of the imposition of the verdict. In addition

\footnotetext{
${ }^{1}$ Student of Master of Law, Universitas Islam Sultan Agung Semarang and Police member, email: endang.kusnandar1977@gmail.com

${ }^{2}$ Lecturer of Master of Law, Sultan Agung Islamic University (UNISSULA), Semarang

${ }^{3}$ Lecturer of Master of Law, Sultan Agung Islamic University (UNISSULA), Semarang
} 
to the difficulties in the definition above, is also the difficulty of proof, for example rape or lewd acts are generally conducted without the presence of others ${ }^{4}$

Sudarto believes (as quoted by Barda Nawawi Arief in his Anthology Criminal Law Policy) to solve crimes that required an effort that is rational from the public, by way of criminal politics. Policies or efforts to combat crime is essentially an integral part of efforts to protect the public (social defense). Therefore, it can be said that the main purpose of criminal politics is "the protection of society to achieve the welfare of the community" $^{5}$

Political criminals associated with crime victims of rape, is still around to provide protection to women both adults and ages of children who are victims of rape, but not touching how to provide legal protection if the rape to bear children, because not all rape victims revealed or reported directly shortly occur rape, but many cases are only revealed when women are generally aged children have been seen enlarged womb, a dilemma if the aborted unborn, as specified in the MUI Fatwa, that abortion is a crime but for rape victims is expected to be of legal protection for those who seek an abortion with in hopes of reducing the suffering experienced. According to the chairman of $\mathrm{MUI}$ " rape victims can have an abortion during the pregnancy age has not reached the age of 40 days, for persecuted not as desired, but because of coercion of a person. The main reason to have an abortion to avoid the controversy about the right to life "6,

Based on the background of the problems that have been mentioned above, then the problem is formulated as follows: What form of legal protection given to the rights of children which born fom rape victims in Ex Residency Cirebon Jurisdiction? What are the obstacles in the implementation of the provision of legal protection against rape victims in Ex Residency Cirebon Jurisdiction and solution?

\section{Research Method}

The method used by researchers is normative juridical law approach and specification in this study were included descriptive analysis. The sources and types of data in this study are primary data obtained from field studies with interview members of the Police of Ciwaringin Cirebon, And secondary data obtained from the study of literature.

\section{Results and Discussion}

\subsection{Forms of Legal Protection of Children Which Born From Rape Victims In Ex Residency Cirebon Jurisdiction}

Region III Cirebon is often also referred to by the abbreviation "Ciayumajakuning" or a continuation of the "Cirebon (city), Indramayu (Majalengka (District) and Kuningan (Regency) is a five-county / city jurisdiction formerly an Ex Residency Cirebon of West Java province. in each of the City and District are included five State Court (PN). PN Cirebon in Cirebon; PN Sumber in Cirebon, PN Indramayu in Indramayu; PN

\footnotetext{
${ }^{4}$ Leden Marpaung, 1996, Kejahatan Terhadap Kesusilaan Dan Masalah Prevensinya, Jakarta: Sinar Grafika, p. 81.

${ }^{5}$ Barda Nawawi Arief, 2002, Bunga Rampai Kebijakan Hukum Pidana, Bandung: Citra Aditya Bakti, p. 1-2.

${ }^{6}$ http: // sipangkar. blogspot.com/2011/03/ makalahaborsi-in-law-di.html
} 
Majalengka; PN Kuningan in Kuningan District. In each of these PN's not a few women both adults and children or who are under the age of 18 (eighteen) years old who are victims of rape. ${ }^{7}$

Rape is a crime that often occur in people's lives. Rape is included in sexual crimes as acts or actions likely to lead to things that are sexuality. Rape may occur in the private and public (community / society), whose victims are always women. Then seen from the age of the victim, rape can occur in those younger adults and children. In the context of positive criminal law, rape is a criminal offense provided for in the Code of Penal (Penal Code).

In the Criminal Code, the crime of rape was categorized as crime (rechtsdelicten) specified in the Second Book (II) Chapter XIV. Rape is categorized as a crime as opposed to the values of justice, regardless of whether the rape punishable under a law or not $^{8}$. Rape as a crime called a crime against morality (misdrijven tegen de zeden), which by legal experts also called the crime regarding the propriety ${ }^{9}$ or crimes against decency ${ }^{10}$

The criminal act of rape which are prevalent in the reality of everyday life resulted in the woman raised the fear, anxiety and insecurity. Moreover, supported by the position of victims who are often powerless in the criminal justice process. That is, the suffering of victims is not bridged by law enforcement. Victim is a conception of reality as well as the object of events. The social construction of the law itself states that every crime has a victim. Their victims are indications that the existing social order is disturbed, therefore, from the standpoint of legality, the victims are often clearly itemized $^{11}$

Rape by judicial construction regulations in Indonesia (the Criminal Code) is the act of forcing a woman who is not his wife to have sex with her by force or threat of violence. The words "force" and "violence or threats of violence" here already shows how horrible rape. The imposition of sexual intercourse in women who do not want it will cause great pain on the woman. What else is accompanied by physical violence. Severe pain can occur not only limited to physical, but also in terms of psychic ${ }^{12}$.

In criminal cases of rape are often the victims are children, girls, women, including the weak mentally, physically and socially sensitive to threats from within and from outside the family. Threats of violence from outside his family, his home often can be driven, as can be seen by him. But the threat of violence in the home by family members themselves are often difficult to be seen by outsiders. In general, the violence is a wife, mother, daughter, female domestic helpers. They often do not dare

\footnotetext{
${ }^{7}$ Results Interview with H. Asep, members of the Police of Ciwaringin, on February 11, 2020, 13:00 pm

${ }^{8}$ Sudarto argued that the crime (rechtsdelicten) is an act contrary to justice, regardless of whether the action was dicancam in a law or not. Sudarto, 2013, Hukum pidana I, Semarang: Penerbit Yayasan Sudarto, p. 94.

${ }^{9}$ The term is used by the crime regarding the propriety wirjono prodjodikoro. See wirjono prodjodikoro 2010, Tindak-Tindak Pidana Tertentu Di Indonesia, Bandung: Refka Aditama, p. 111.

10 The term crimes against decency used by R. Soesiolo. See R. Susilo, 1995, Undang-Undang Hukum Pidana (KUHP) Serta Komentar-Komentarnya Lengkap Pasal Demi Pasal, Bogor: Politeia, p. 204.

${ }^{11}$ Mulyana W. Kusuma, 1981, Aneka Permasalahan Dalam Ruang Lingkup Kriminologi, Bandung: Alumni, p. 109.

12 Suryono Ekotama, Harum Pudjiarta and Widiartana, 2001, Abortus Provocatus, Bagi Korban Perkosaan Perspektif: Viktimologi dan Widiartana, Yogyakarta: Universitas Atmajaya, p.96.
} 
to report, among others because of family ties, specific social values, the good name of a specific and difficulties that are expected to arise if the relevant report ${ }^{13}$.

Legal protection is the cornerstone of an element of a state of law, because legal protection is the right of every citizen and the obligations of the state as the organizer of protection. State provides protection by arranging them in a variety of legislation, one of which is contained in Article 76D of Act No. 35 of 2014 concerning amendments to the Act No. 23 of 2002 on the Protection of the Child which states: "Everyone is prohibited from engaging in violence or threats of violence to force child sexual intercourse with him or with anyone else."

Forms of legal protection given to Children Which Born fom rape victims in Ex Residency Cirebon Jurisdiction, as is the case in the jurisdiction of other areas, merely enacted regional regulation on Child Protection, but the regulation is not set up for a child born to mothers who were raped or pregnancy due to rape, as well as court decisions, no one has noticed rape victims the pregnancy due to rape, both already known since the proceedings nor be known after the imposition of the verdict (ponis), as well as the Agency duties and authorities are not up to provide protection to Children Which Born from rape, but the child of such status as well as victims.

\subsection{Constraints in Implementing Provision of Legal Protection Against Rape Victims In Ex Residency Cirebon Jurisdiction and the Solution}

Speaking of legal protection of Children Which Born out of rape victims of crime in the future must not be separated from the equilibrium value of criminal law itself in the creation of the legal protection of Children Which Born out of rape victims of crime as a whole and dynamic. Development of criminal law in Indonesia, which are based on the thoughts flow the classic (classic school) or flow Daad-Strafrech focusing on aspects of the criminal act and develop in the 18th century ${ }^{14}$. When viewed from a balance between the offender and the victim is required to balance or refund the victims suffering both physical and non-physical.

Further ahead Judges and prosecutors need to be learning again to dare to read the text freely prioritizing the protection of victims (Children Which Born from rape crime victims), which is put on the social context and the social objective of the present. Not the least of law texts that can impair the victim if it is not read and interpreted as a progressive in the protection of victims. Judges and prosecutors should not hesitate in deciding the case in considering the rights and casualty losses (Children Which Born from rape victims of crime) of origin could give arguments. Important arguments that can be proposed should venture out of the suit and put liberal mind to serve the legal function, ensure and maintain the integrity of Indonesia ${ }^{15}$. The argument on the other not used to maintain the integrity of Indonesia in this context can not be separated from the interests of the victims of fighting in order to achieve protection in the form of restitution from the offender is given to victims (Children Which Born from rape

\footnotetext{
${ }^{13}$ Arif Gosita, 1985, Victimisasi Kriminal Kekerasan, Second Edition, Jakarta: Akademika Presindo, p. 45.

${ }^{14}$ Muhammad Sholehidin, 2004, Sistem Sanksi Dalam Hukum Pidana; Ide Dasar Double Track Sistem Dan Implenetasinya, Jakarta: Raja Grafindo Persada, p 25.

15 Satjipto Rahardjo, 2009. Hukum Progresif sebuah Sintesa Hukum Indonesia, First Edition, Yogyakarta: Yogyakarta Publising Gentta, p. 144.
} 
crime victims).

In the Implementation Granting Legal Protection Against Rape In Ex Residency Cirebon Jurisdiction there are some obstacles encountered in providing legal protection for the victims of rape. These constraints were: ${ }^{16}$ Victims who do not open in providing information and psychological disorder victims; The difficulty in finding witnesses; Not Having Kids Investigators; Facilities and infrastructures.

Efforts are being made to overcome the obstacles faced In the Implementation Granting Legal Protection Against Rape In Ex Residency Cirebon Jurisdiction are as follows: ${ }^{17}$

- To overcome the constraints of children who can not give the worker openly will involve the parents in order to help to persuade children to give information to investigators. However, if the child concerned is difficult to give a description, then their parents will help tell the criminal offense experienced by the child to the investigator. For the problem of child psychology, in collaboration with the Department of Social Welfare to restore the child's mental. Every case of rape against children are addressed, they will always tell the social services, social services later that will provide expert Psychology to children with mental conditions are really annoyed because the criminal events that he experienced.

- Witness difficult for questioning, will try to convince the witness to be willing to provide testimony. By assuring that what will be told only that information only, what he saw.

- Because the child has no special investigator then, in the jurisdiction of Ex Residency Cirebon order an investigation conducted by the same investigator for adults.

- To cope with facilities and infrastructures jurisdiction ex Residency alternately Cirebon checks for child victims of rape by adults.

\section{Closing}

\subsection{Conclusion}

- Forms of legal protection given to Children Which Born fom rape victims in Ex Residency Cirebon Jurisdiction, as is the case in the jurisdiction of other areas, merely enacted regional regulation on Child Protection, but the regulation is not set up for a child born to mothers who were raped or pregnancy due to rape, as well as court decisions, no one has noticed the rape victim which the pregnancy due to rape, both already known since the proceedings nor be known after the imposition of the verdict (ponis), as well as the Agency duties and authorities are not up to provide protection to Children Which Born from rape, but the child of such status as well as victims.

- Some of the obstacles include the difficulty to obtain information from the victim because of the victim's mental condition of the child, still quite a lot of people who are reluctant to testify as a witness, investigators have no children, and infrastructure are not yet complete. To overcome the obstacles faced by those already undertaken several measures, among others cooperate with relevant

\footnotetext{
${ }^{16}$ Results Interview with H. Asep, members of the Police of Ciwaringin, on February 11, 2020, 13:00 pm ${ }^{17}$ Ibid.
} 
agencies to provide protection and assistance to child victims of rape, bring in psychologists to recover the child's mental disturbed for being a victim of rape cases, as well as trying to convince the witness that willing to give information and not to be afraid to give testimony to the investigator.

\subsection{Suggestion}

- When the witness and victim protection agencies can not afford to seek legal protection such as restitution or compensation to victims it is time for all the responsibilities handed over to the police or the prosecutor's office because of the existence of witness and victim protection agency standing outside law enforcement agencies such as police or prosecutors. So that later from the investigator or the prosecutor in charge of seeking legal protection as restitution and compensation to victims.

- In order to reform the Penal Code which will come associated with the protection of children, it must be in the Penal Code relating to the protection of Children Which Born out of rape either raped by which no blood or the blood (incest), to determine the intended protection, should the manufacturer enactment legislation involving the MUI for the protection of Children Which Born out of rape victims related to religion and not to be contrary to Article 29 paragraph (1) Constitution of the Republic of Indonesia 1945.

\section{REFERENCES}

[1] Arif Gosita, 1985, Victimisasi Kriminal Kekerasan, Second Edition, Jakarta: Akademika Presindo

[2] Barda Nawawi Arief, 2002, Bunga Rampai Kebijakan Hukum Pidana, Bandung: Citra Aditya Bakti

[3] http: // sipangkar. blogspot.com/2011/03/ makalahaborsi-in-law-di.html

[4] Wirjono prodjodikoro 2010, Tindak-Tindak Pidana Tertentu Di Indonesia, Bandung: Refka Aditama

[5] R. Soesiolo. See R. Susilo, 1995, Kitab Undang-Undang Hukum Pidana (KUHP) Serta Komentar-Komentarnya Lengkap Pasal Demi Pasal, Bogor: Politeia

[6] Leden Marpaung, 1996, Kejahatan Terhadap Kesusilaan Dan Masalah Prevensinya, Jakarta: Sinar Grafika

[7] Muhammad Sholehidin, 2004, Sistem Sanksi Dalam Hukum Pidana; Ide Dasar Double Track Sistem Dan Implenetasinya, Jakarta: Raja Grafindo Persada

[8] Mulyana W. Kusuma, 1981, Aneka Permasalahan Dalam Ruang Lingkup Kriminologi, Bandung: Alumni

[9] Satjipto Rahardjo, 2009. Hukum Progresif sebuah Sintesa Hukum Indonesia, First Edition, Yogyakarta: Yogyakarta Publising Gentta

[10] Sudarto, 2013, Hukum pidana I, Semarang: Penerbit Yayasan Sudarto

[11] Suryono Ekotama, Harum Pudjiarta and Widiartana. 2001, Abortus Provocatus, Bagi Korban Perkosaan Perspektif: Viktimologi dan Widiartana, Yogyakarta: Universitas Atmajaya 